\title{
Change of telomere length in angiotensin II-induced human glomerular mesangial cell senescence and the protective role of losartan
}

\author{
XIN FENG ${ }^{1,3}$, LINING WANG ${ }^{1}$ and YAO LI $^{2}$ \\ ${ }^{1}$ Department of Nephropathy, First Affiliated Hospital of China Medical University, Shenyang, Liaoning 110001; \\ ${ }^{2}$ Department of Physiology, Liaoning Medical University, Jinzhou, Liaoning 121000, P.R. China
}

Received October 22, 2010; Accepted January 19, 2011

DOI: $10.3892 / \mathrm{mmr} .2011 .436$

\begin{abstract}
Telomeres are DNA repeats at the ends of linear chromosomes in eukaryotic cells; they form cap-like specialized structures at chromosome ends to protect them from digestion and degradation. With each cell division, somatic cell telomeres progressively wear and shorten, leading to cell senescence. Various environmental factors, such as oxidative stress and inflammation, can accelerate telomere shortening. The renin angiotensin system seems to be the key mechanism involved in aging. Our previous studies demonstrated that treatment of human glomerular mesangial cells (GMCs) with angiotensin II (AngII) caused cell senescence. It is important to understand whether AngII accelerates telomere shortening in GMCs and further promotes aging. Therefore, this study was designed to investigate the change in telomere length in AngII-induced GMC senescence and the role of the AngII receptor antagonist losartan in delaying this process. The cells were synchronized and divided into a normal control group, an AngII group (AngII, $10^{-6} \mathrm{~mol} / \mathrm{l}$ ) and an AngII + losartan group (losartan, $10^{-5} \mathrm{~mol} / \mathrm{l}$ ), and were then cultured for $72 \mathrm{~h}$. The telomere lengths were analyzed by Southern blot analysis, cell morphology was monitored, the cell cycle and $\beta$-galactosidase staining were determined, and the expression of P53 and P21 proteins was assessed by Western blotting. Compared with the control group, the AngII group exhibited a markedly reduced telomere length, cell cycle arrest, enhanced $\beta$-galactosidase staining, and elevated expression of P53 and P21. The AngII + losartan group displayed longer telomere lengths, further reduced $\beta$-galactosidase staining and decreased P53 and P21
\end{abstract}

Correspondence to: Professor Lining Wang, Department of Nephropathy, The First Affiliated Hospital of China Medical University, No. 155, Nanjing North Street, Heping, Shenyang, Liaoning 110001, P.R. China

E-mail: liningwang1956@hotmail.com

Present address: ${ }^{3}$ Department of Nephropathy, The First Affiliated Hospital of Liaoning Medical College, Jinzhou, Liaoning, P.R. China

Key words: senescence, angiotensin II, telomere length, losartan expression compared to the AngII group. This study confirms that AngII induces the shortening of telomere lengths, P53 and P21 expression, cell cycle arrest, and the resulting cell senescence in GMCs. In addition, losartan significantly reduced telomere shortening and cell senescence.

\section{Introduction}

Aging is the gradual functional decline of human tissues and organs exposed to long-term internal and external environmental pressure. The kidney is one of the first organs to age in humans, and the incidence of chronic kidney disease in the elderly increases yearly (1-3). The need for renal replacement therapy among these patients is rapidly increasing. A number of reviews describing the overall function of the aging kidney have been written, and investigating the mechanism of kidney aging and protecting the functions of the aged kidney have become major focuses for scholars.

The mechanisms of kidney aging remain unclear. Oxidative stress, telomere length, Klotho gene expression and the renin angiotensin system (RAS) seem to be the key mechanisms involved in aging (4). Telomeres are specific DNA/protein complexes that protect the ends of eukaryotic chromosomes. Human telomere DNA is composed of the evolutionarily conserved [5'-TTAGGG-3'] serial repeats with a total length of approximately $5-15 \mathrm{~kb}$. These cover both ends of chromosomes like caps to protect the integrity and stability of chromosomes and to protect them from degradation, fusion and rearrangement (5). However, the telomeres of somatic cells become worn and shortened during cell division; each division causes a reduction in the telomere length $(6,7)$. When the length of the telomeres is reduced to a certain level, it can activate P53 and P21, causing cell growth arrest and ultimately leading to cell death. In the past few years, research has focused on telomeres in order to find new therapeutic targets. However, the change in telomere length in senescent human glomerular mesangial cells (GMCs) has not yet been investigated.

Telomere shortening can cause cell replicative senescence. Some environmental factors, such as oxidative stress and inflammation, are associated with the acceleration of telomere shortening. Angiotensin II (AngII) is the major functional 
peptide in RAS. In vivo and in vitro experiments have shown that aging is accompanied by reduced RAS activity. Increased AngII synthesis in heart muscles and blood vessels, as well as augmented receptor density suggest the role of AngII in aging $(8,9)$. Therefore, further studies are required to determine whether AngII accelerates telomere shortening in GMCs and promotes aging.

In this study, GMCs were stimulated with AngII. We then examined the change in telomere length and the expression of the cyclin-dependent kinase inhibitors P53 and P21. Additionally, losartan was introduced to the aged cells, and its effects on mesangial cell senescence were examined.

\section{Materials and methods}

Materials. Human renal mesangial cell culture medium was purchased from ScienCell Company (USA). AngII and rabbit monoclonal antibodies specific for P53 and P21 were obtained from Sigma, and a telomere length determination kit was obtained from Roche. Losartan was kindly provided by Merck.

Culture of human glomerular mesangial cells. GMCs were obtained from ScienCell Research Laboratories (Carlsbad, CA, USA) and cultured in mesangial cell medium supplemented with $10 \%$ fetal bovine serum, $100 \mathrm{U} / \mathrm{ml}$ penicillin and $100 \mu \mathrm{g} / \mathrm{ml}$ streptomycin at $37^{\circ} \mathrm{C}$ in a humidified atmosphere of $5 \% \mathrm{CO}_{2}$ in air. The cells were grown to $80-90 \%$ confluence in $25-\mathrm{cm}^{2}$ culture flasks and subcultured at a ratio of $1: 2$. Cells from passages 5-8 were used. For the experiments, cells were synchronized by culturing in serum-free medium for $24 \mathrm{~h}$ to ensure G0 arrest. At this point, a final concentration of AngII $\left(10^{-6} \mathrm{~mol} / \mathrm{l}\right)$ was added to the culture medium, and cells were stimulated for $72 \mathrm{~h}$. Losartan $\left(10^{-5} \mathrm{~mol} / \mathrm{l}\right)$ was added $1 \mathrm{~h}$ prior to the addition of AngII. Medium overlying the cells was supplemented with AngII and losartan on alternate days.

Cell morphology. The cells were monitored under a microscope. Morphologic changes in the senescent cells were evaluated using optical microscopy. The cells were washed twice with PBS and examined using an Olympus optical microscope.

Cell cycle analysis. Up to $1 \times 10^{6}$ cells were digested, collected, centrifugated at $1000 \mathrm{rpm}$ for $5 \mathrm{~min}$, and fixed with $70 \%$ ethanol at $4^{\circ} \mathrm{C}$ overnight. Ethanol was removed by centrifugation. The cells were then washed twice with PBS supplemented with propidium iodide dye (PI) to a final concentration of $50 \mu \mathrm{g} / \mathrm{ml}$, and incubated in the dark at $4^{\circ} \mathrm{C}$ for $30 \mathrm{~min}$. The cell cycle was analyzed by flow cytometry at an excitation wavelength of $488 \mathrm{~nm}$, an emission wavelength of $570 \mathrm{~nm}$, and a cell flow rate of $\leq 60$ cells/min; at least 10,000 cells were selected. The data were analyzed by Moldifit 2.0.

$\beta$-galactosidase staining. The cells were grown to $80 \%$ confluence, washed 3 times with PBS, and fixed at room temperature for $5 \mathrm{~min}$ (fixation solution: $2 \%$ formaldehyde, $0.2 \%$ glutaraldehyde). The cells were then washed 3 times with PBS and stained with freshly prepared $1 \mathrm{ml}$ senescenceassociated $\beta$-galactosidase staining fluid at $37^{\circ} \mathrm{C}$ (without $\mathrm{CO}_{2}$ ) for $12-16 \mathrm{~h}$. The blue precipitates in the cytoplasm were analyzed. Six fields were randomly selected in each sample, and the percentage of positive cells was calculated.

Southern blot analysis. Genomic DNA was prepared using a cell genomic DNA extraction kit. Two micrograms of DNA sample or control sample were digested overnight with restriction enzyme $\operatorname{HinfI} / R s a \mathrm{I}$ at $37^{\circ} \mathrm{C}$, and the digested fragments were separated with $0.8 \%$ agarose gel electrophoresis. The gel was immersed in 0.25 M HCL solution for 5-10 min until the blue bromophenol turned yellow. The gels were then incubated in denaturing solution on a plate shaker for $15 \mathrm{~min}$ twice, and then soaked in a neutralizing solution for $30 \mathrm{~min}$. Filter paper, gel, a nylon membrane, filter paper and a paper towel were sequentially placed on a bench with a $500 \mathrm{~g}$ item on top. After overnight transfer, the nylon membrane was cross-linked under $10 \mathrm{~cm}$ of UV light for $20 \mathrm{~min}$ and washed twice with $2 \mathrm{X}$ saline-sodium citrate buffer. Then, $25 \mathrm{ml}$ prehybridization solution (DIG Easy Hyb) was preheated to $42^{\circ} \mathrm{C}$, and $18 \mathrm{ml}$ pre-hybridization solution and the nylon membrane were pre-hybridized at $42^{\circ} \mathrm{C}$ for $1 \mathrm{~h}$ in a hybridization bag. The $1 \mu 1$ membrane was hybridized at $42^{\circ} \mathrm{C}$ for $3 \mathrm{~h}$ in a solution containing $1 \mu \mathrm{l}$ telomerase probe and the remaining $7 \mathrm{ml}$ pre-hybridization solution. The membrane was then washed twice with stringent wash buffer I, once with preheated stringent wash buffer II for $20 \mathrm{~min}$, and once with 1X washing buffer for $5 \mathrm{~min}$. The membrane was then blocked in blocking solution for $30 \mathrm{~min}$ and incubated at room temperature for $30 \mathrm{~min}$ in an antibody working solution of anti-DIG-AP antibodies in fresh blocking solution at 1:10,000. The membrane was washed with $1 \mathrm{X}$ washing buffer and $1 \mathrm{X}$ detection buffer for $3 \mathrm{~min}$, and then $4 \mathrm{ml}$ substrate solution was introduced dropwise. The film was developed in a dark room after 5 min of exposure in the developing cassette. The signal strength of the bands was measured using Kodak Digital Sciences 1D ${ }^{\mathrm{TM}}$ software, and the average telomere terminal restriction fragment (TRF) length was calculated via the formula $\mathrm{TRF}=\Sigma$ (Ai) $/ \Sigma(\mathrm{Ai} / \mathrm{Li})$, where $\mathrm{Ai}$ and $\mathrm{Li}$ represent the signal intensity and the TRF length at position I of the X-ray image, respectively. The experiments were repeated three times.

Western blot analysis. The cells were collected after stimulation, lysed with RIPA solution and centrifugated at 12,000 x $\mathrm{g}$ at $4^{\circ} \mathrm{C}$ for $5 \mathrm{~min}$. The supernatant was collected, and the protein concentration was determined by bicinchoninic acid assay. Protein samples were made in equal concentrations, separated by $8 \%$ SDS-polyacrylamide gel electrophoresis $(80 \mathrm{~V}, 1 \mathrm{~h})$, and electrically transferred onto a nitrocellulose membrane $(60 \mathrm{~V}, 3 \mathrm{~h})$. After blocking with $5 \%$ non-fat dry milk for $2 \mathrm{~h}$, the membrane was incubated overnight with P53 or P21 antibodies and with secondary antibodies at room temperature for $2 \mathrm{~h}$. Color was developed using the alkaline phosphatase approach, and a quantitative analysis of grey intensity was performed with Scinn Corporation software. The experiment was repeated three times, and the arithmetic mean was used for statistical analysis.

Statistical analysis. The experimental data were presented as the mean \pm standard deviation and analyzed with SPSS 13.0 statistical software. The inter-group data were compared via ANOVA; $p<0.05$ was considered statistically significant. 


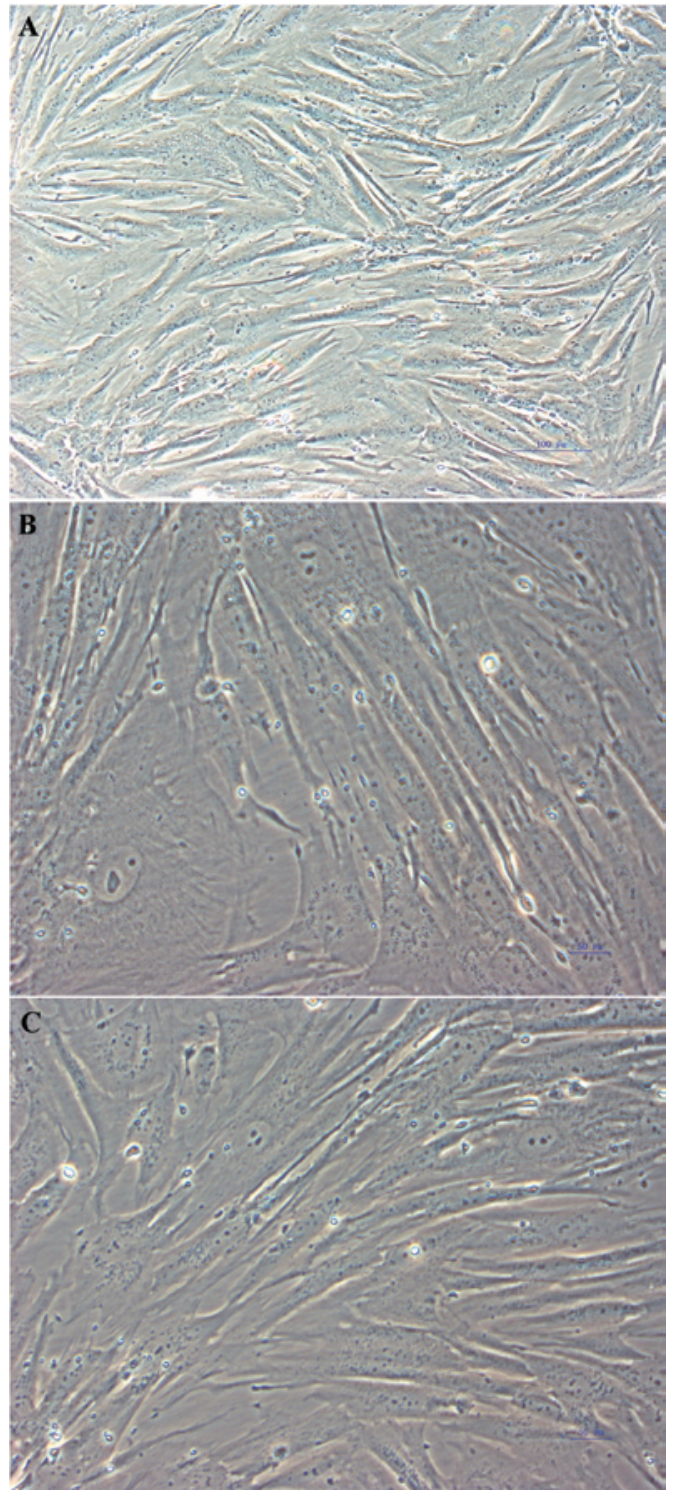

Figure 1. Images of (A) control cells, (B) AngII-induced senescent cells and (C) losartan + AngII-stimulated cells captured under optical microscopy. Original magnification, x100. Typical results of three independent experiments are shown.

\section{Results}

AngII-induced GMC senescence. We first determined whether AngII stimulates the cellular senescence of GMCs. Optical electron microscopy was used to evaluate the morphologic alterations in the GMCs. In the control group, the cells displayed a well-arranged spindle morphology, and more dividing cells and clear cell borders were noted. In the AngII group, the cells exhibited an irregular arrangement, with large sizes, flat morphology and an enlarged cytoplasmic area. Abundant particles and vacuoles were observed in the cytoplasm. The cells exhibited fuzzy boundaries, prolonged time to form a confluent monolayer, reduced number and decreased vitality (Fig. 1A and B). Next, $\beta$-galactosidase staining, a reliable biomarker for cellular senescence, was used to determine whether the replicative arrest was associated with senescence. After treatment with AngII for $72 \mathrm{~h}, \beta$-galactosidase staining in the GMCs of the AngII group (85.62 \pm 6.09$)$ was significantly increased
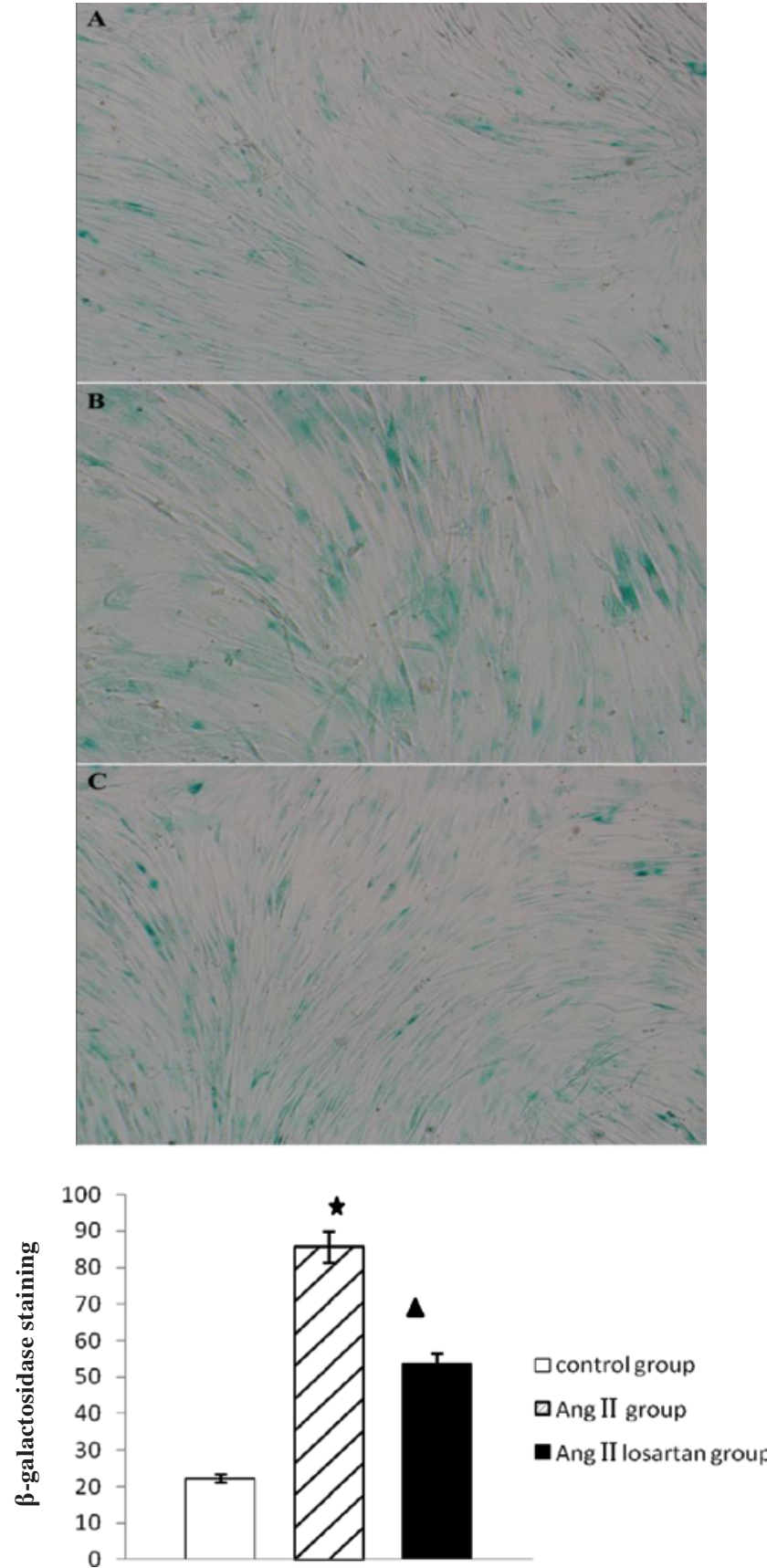

Figure 2. Senescence-associated- $\beta$-galactosidase activity in GMCs. (A) Control cells, (B) AngII-induced senescent cells and (C) losartan + AngII-stimulated cells. Original magnification, $\mathrm{x} 200$. Results are representative of two regions from three independent experiments. ${ }^{*} \mathrm{P}<0.05$ vs. control group; ${ }^{\wedge} \mathrm{P}<0.05$ vs. AngII group.

compared to the control cells $(22.11 \pm 3.19, \mathrm{p}<0.05)$ (Fig. 2A and B). This indicated that AngII promoted cellular senescence in the GMCs. Flow cytometry was used to characterize the nature of cell cycle arrest. A normal cell phase distribution was noted in the control group, while the cell cycle was arrested at the G0/G1 phase in the AngII-induced group $(92.11 \pm 6.56 \%)$ compared to the control cells $(53.12 \pm 3.23 \%, \mathrm{p}<0.05)$. The $\mathrm{S}$ and $\mathrm{G} 2 / \mathrm{M}$ phases tended to disappear in the AngII-induced cells compared to the control cells $(6.12 \pm 0.32$ and $2.38 \pm 0.23 \%$; $25.77 \pm 1.34$ and $13.12 \pm 1.16 \%$ respectively; $p<0.05$ ) (Fig. 3). These results indicated that the cells were arrested by AngII at the G0/G1 phase. 
A

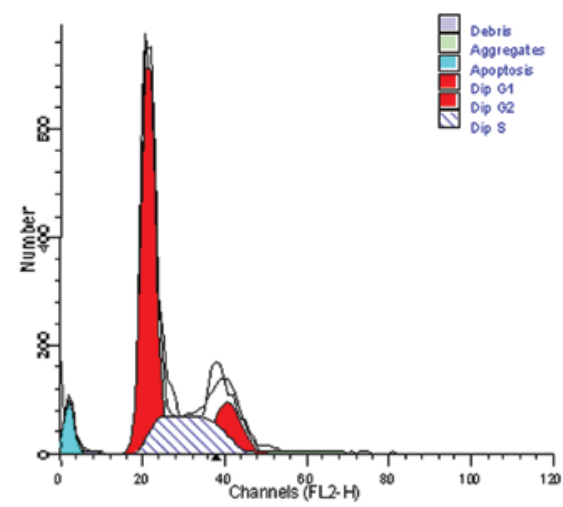

B

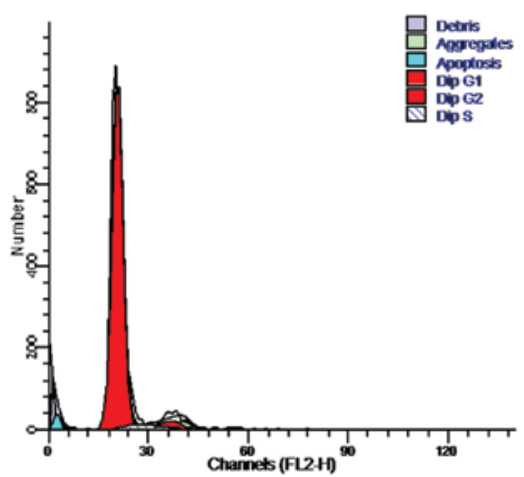

C
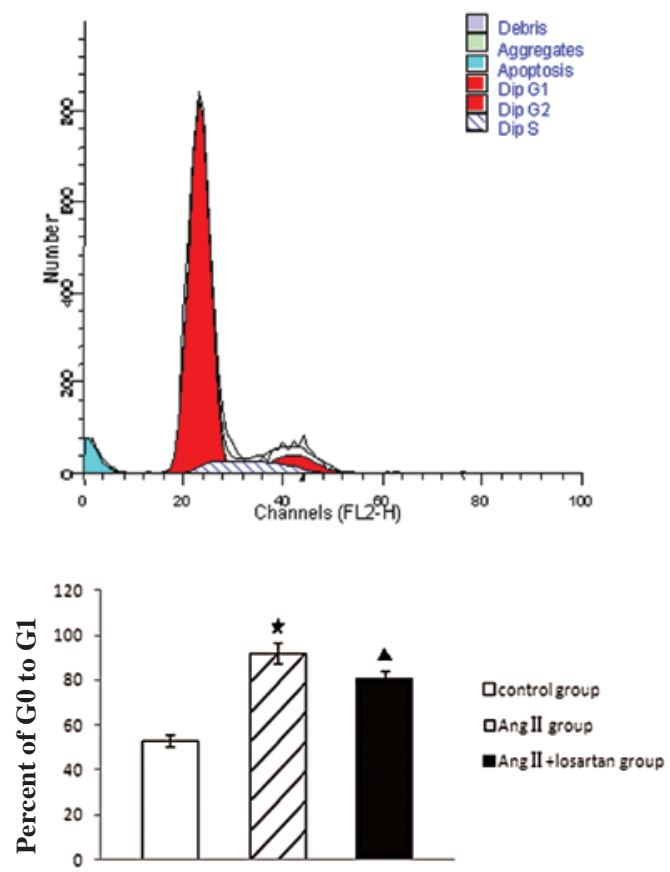

Figure 3. Flow cytometric cell cycle analysis of (A) control cells, (B) AngIIinduced senescent cells and (C) losartan + AngII-stimulated cells. Typical results of three independent experiments are shown. ${ }^{*} \mathrm{P}<0.05$ vs. control group; $\wedge \mathrm{P}<0.05$ vs. AngII group.

AngII accelerates telomere shortening in cultured GMCs. The reduction in telomere length is one of the events in aging. We thus investigated the effect of AngII on TRF length in GMCs by Southern blot analysis. In the control group, TRF length was $6.13 \pm 0.076 \mathrm{~kb}$. AngII-stimulated GMCs had a lower TRF length $(3.03 \pm 0.096 \mathrm{kp})$ than the control group. These results revealed a significant loss of telomere DNA in GMCs after $72 \mathrm{~h}$ of treatment with AngII (Fig. 4).
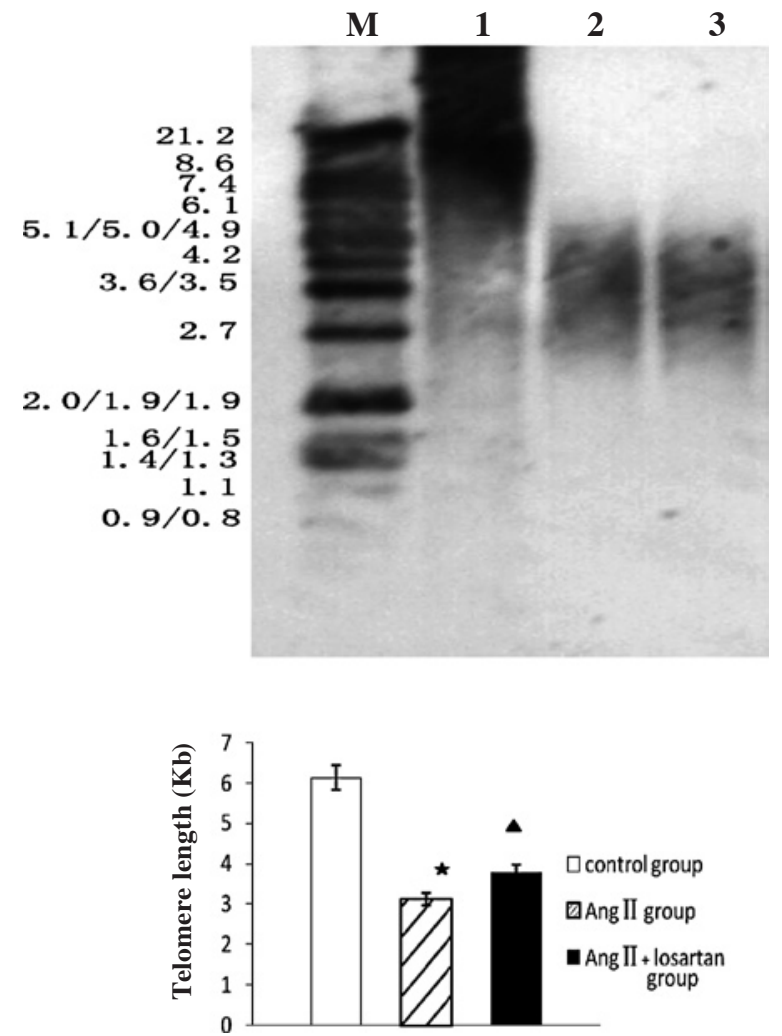

Figure 4. Average telomere (TRF) length in the cells was measured by Southern blot analysis. (1) Control cells, (2) AngII-induced senescent cells, (3) losartan + AngII-stimulated cells. Typical results of three independent experiments are shown. ${ }^{*} \mathrm{P}<0.05$ vs. control group; ${ }^{\wedge} \mathrm{P}<0.05$ vs. AngII group.

p53 and p21 protein expression in aging. $\mathrm{P} 53$ and $\mathrm{P} 21$ play the role of cell cycle checkpoint regulators in cell senescence. The reduction in telomere length is one of the events leading to activation of P53 and downstream P21 signaling, To determine changes in P53 and P21 during the process of GMC senescence stimulated by AngII, Western blot analysis was performed. Expression of P53 and P21 was barely detectable in the control group. In sharp contrast, both P53 and P21 proteins were significantly elevated in the AngII group (Fig. 5).

Function of losartan in the delayed aging of GMCs. Optical microscopy revealed losartan + AngII-stimulated cells to be regularly aligned with decreased pulp-lysosome and a smooth nuclear membrane (Fig. 1C). $\beta$-galactosidase staining was significantly weaker in the AngII + losartan group (53.73 \pm 3.76$)$ than in the AngII group (85.62 \pm 6.09 ) (Fig. 2B and C). Cell cycle analysis indicated that the AngII + losartan group displayed a significantly lower G0/G1 cell ratio and a higher $\mathrm{S}$ and $\mathrm{G} 2 / \mathrm{M}$ cell ratio when compared to the AngII group (Fig. 3). These changes indicate that losartan delays cellular senescence in GMCs induced by AngII. The telomere length in the AngII + losartan group $(3.99 \pm 0.066 \mathrm{~kb})$ was longer than that in the AngII group ( $3.03 \pm 0.096 \mathrm{~kb})$, but still shorter than that of the control group (Fig. 4). Expression of P53 and P21 was decreased in the AngII + losartan group, but was still higher than that of the control group. These changes confirm that AngII induces the shortening of telomere length and P53 and P21 expression in senescent GMCs (Fig. 5). 

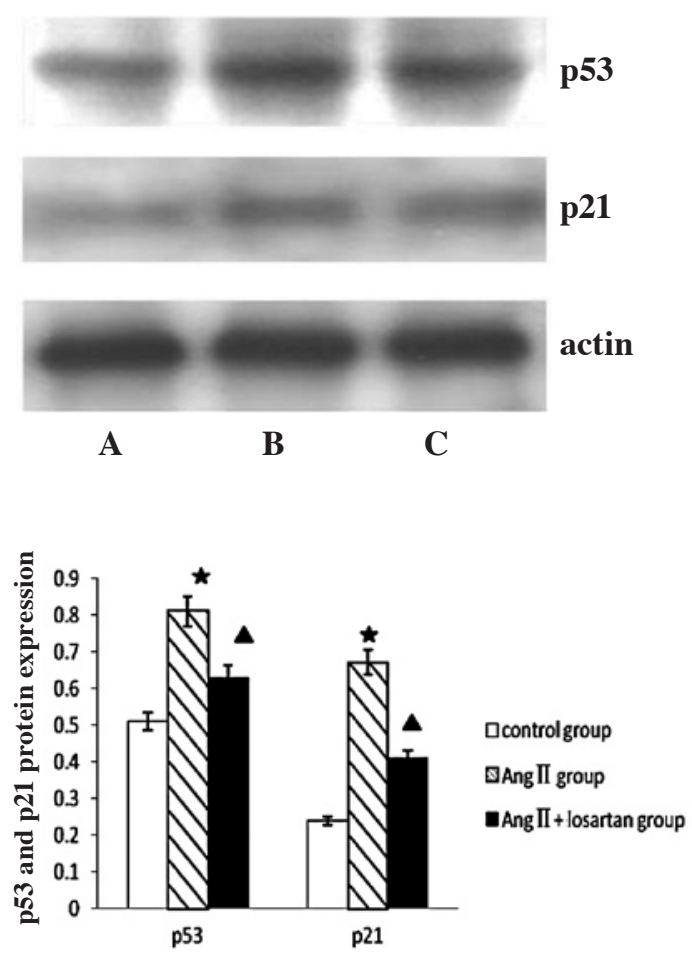

Figure 5. Western blot analysis of P53 and P21 expression. Lane A, control cells; B, AngII-induced senescent cells; C, losartan + AngII-stimulated cells. ${ }^{*} \mathrm{P}<0.05$ vs. control group; $\triangleleft \mathrm{P}<0.05$ vs. AngII group.

\section{Discussion}

Cells are the constituent units of the body. The aging of the body caused by cell senescence, the senescence of key cells, is the pathological basis for the aging of organs and tissues. Glomerular mesangial cells are among the most important intrinsic cells, and changes in their phenotype and function play crucial roles in the aging of the kidney. Elucidating the mechanism of kidney aging by understanding the phenotypic and functional changes during aging is vital.

AngII plays an important role in the occurrence and development of kidney aging. AngII promotes the transformation of renal fibroblasts into myofibroblasts, which stimulates transforming growth factor- $\beta$ production, oxidative stress, mesangial cell hypertrophy and hyperproliferation, and mesangial matrix collagen synthesis, leading to glomerular sclerosis $(10,11)$. Our previous studies showed that treatment of human mesangial cells with AngII caused senescence. Therefore, in this study, AngII was used to stimulate human mesangial cells. We noted evident cell senescence and phenotypes including aging-related morphology with larger and a greater number of cytoplasmic particles, cell growth arrest in the G0/G1 phase, and increased $\beta$-galactosidase staining. These characteristics indicated that AngII successfully induced GMC senescence and established a senescence model.

At present, the mechanism of kidney aging remains unclear. One important mechanism responsible for cellular senescence is progressive telomere shortening and eventual telomere dysfunction, which occurs due to incomplete DNA replication at the telomeres (12-15). Telomere shortening has been called the molecular clock that triggers senescence. Shortened leukocyte telomere length is observed in a host of aging-related complex genetic diseases, and is associated with diminished survival in the elderly (16). Melk et al confirmed that telomeres are progressively shortened in human kidneys with increasing age, and that this phenomenon is more evident in the cortex than in the medulla (17). However, the change in telomere length in senescent human mesangial cells has not been investigated.

Telomere shortening can cause cell replicative senescence, whose difference among cells cannot be explained by the telomere theory. The replicative capability of individual cells in the same cell lines is highly variable, indicating the randomness of telomere shortening. Some environmental factors, such as oxidative stress, possibly accelerate telomere shortening through the injury of telomeric DNA, thus speeding up the aging of cells $(10,18,19)$. AngII plays an important role in the occurrence and development of kidney aging, but whether AngII can accelerate telomere shortening is still unknown. In this study, we evaluated the change in telomere length in AngII-induced GMC senescence. Our results revealed that, compared with the control group, the AngII group exhibited a markedly reduced telomere length. This indicates that AngII accelerates telomere shortening in mesangial cells, which may be an important mechanism of AngII-stimulated cell senescence.

The mechanism by which telomere shortening causes cell senescence is still unknown. Current evidence indicates that when the telomere length is reduced to 5-7 kb, the cell cycle checkpoint P53 is switched on, which induces P21 expression. P53 recognizes shortened telomeres as DNA double-strand breaks; consequently the cell cycle is halted and cells enter the M1 stage. When the telomere length reaches 2-4 kb, the cells enter the M2 phase, chromosomes become unstable, and rearrangement occurs with the formation of dicentric chromosomes and aneuploidy, consequently leading to replicative senescence and death (20). Using telomerase and P53 single or double knockout models, Kusumoto et al (21) found that the loss of telomere DNA activated P53 and P21 causing cell cycle arrest; conversely, the loss of P53 promoted telomere shortening and enhanced the frequency of chromosomal integration. We further determined the expression of P53 and P21 in senescent GMCs. Compared with the control group, the AngII group exhibited significantly reduced telomere length and elevated expression levels of P53 and P21 proteins, indicating that telomere shortening activates P53 and P21, causing cell growth arrest. These findings indicate that the telomere-based P53-P21 pathway plays an important role in the senescence of GMCs.

AngII-induced oxidative stress accelerates telomere shortening and cell senescence. Consequently, we determined whether blocking AngII reduces telomere shortening under oxidative stress. In the majority of cases, inhibition of RAS has proved effective in improving renal structure and function in aging mice and rats $(22,23)$. Previous studies have demonstrated that chronic administration of losartan prevents age-associated changes in the rat kidney (24). As an antagonist of the type I AngII receptor, losartan blocks the binding of AngII and its receptor, as well as the associated biological signal. Losartan reduces glomerular capillary pressure, improves renal hemodynamic abnormalities, relieves early symptoms of high filtration and high perfusion, reduces urine 
protein and protects renal function. In this study, AngII was used to induce mesangial cell senescence, and the effects of losartan on AngII-stimulated mesangial cells were examined. Compared with the AngII group, the AngII + losartan group displayed markedly increased telomere length, a reduced proportion of G0 to $\mathrm{G} 1$ cells and decreased $\beta$-galactosidase staining, indicating that losartan reduces AngII-induced telomere shortening and senescence in mesangial cells, resulting in the protection of renal functions.

In summary, our data confirm that, in GMCs, AngII accelerates telomere shortening causing cell cycle arrest, possibly through further activation of P53 and P21, resulting in cell senescence. AngII is a supplementary environmental factor that accelerate aging-related telomere shortening. Losartan alleviates AngII-induced telomere shortening in mesangial cells, thereby reducing cell senescence. The results of our study, which addressed AngII-induced cell senescence, may not be applicable to other causes of kidney senescence. Further studies are warranted to understand the mechanisms of kidney ageing.

\section{Acknowledgements}

This study was supported by a grant from the Major Basic Project of China (973), no. 2007CB507400. The authors wish to thank Merck for providing the losartan.

\section{References}

1. Roland Sehmitt and Lloyd G Cantley: The impact of aging on kidney repair. Am J Physiol Renal Physiol 294: 1265-1272, 2008.

2. Famulski KS and Halloran PF: Molecular events in kidney aging. Curr Opin Nephrol Hypertens 14: 243-248, 2005.

3. Kiberd BA and Clase CM: Cumulative risk for developing end-stage renal disease in the US population. Am J Soc Nephrol 13: 1635-1644, 2002.

4. Zhou XJ, Saxena R, Liu Z, Vaziri ND and Silva FG: Renal senescence in 2008: progress and challenges. Int Urol Nephrol 40: 823-839, 2008.

5. Jiang H, Ju Z and Rudolph KL: Telomere shortening and ageing. Z Gerontol Geriat 40: 314-324, 2007.

6. Blackburn EH: Switching and signaling at the telomere. Cell 106: 661-673, 2001.

7. Garbe J, Wong M and Wigington D: Viral oncogenes accelerate conversion to immortality of cultured conditionally immortal human mammary epithelial cells. Oncogene 18: 2169-2180, 1999.
8. Weidmann P, De Myttenaere-Bursztein S and Maxwell MH: Effect of aging on plasma renin and aldosterone in normal man. Kidney Int 8: 325-333, 1975.

9. Imanishi T, Kobayashi K, Kuroi A, Ikejima $\mathrm{H}$ and Akasaka T: Pioglitazone inhibits angiotensin II-induced senescence of endothelial progenitor cells. Hypertens Res 31: 757-765, 2008.

10. Long DA, Price KL and Herrera-Acosta J: How does angiotensin II cause renal injury. Hypertension 43: 722-723, 2004.

11. Min LJ, Mogi M, Iwai M and Horiuchi M: Signaling mechanisms of angiotensin II in regulating vascular senescence. Ageing Res Rev 8: 113-121, 2009.

12. Percy C, Pat B, Poronnik P and Gobe G: Role of oxidative stress in age-associated chronic kidney pathologies. Adv Chron Kidney Dis 12: 78-83,2005.

13. Harman D: The free radical theory of aging. Antioxid Redox Signal 5: 557-561, 2003.

14. Blackburn EH and Gall JG: A tandemly repeated sequence at the termini of the extrachromosomal ribosomal RNA genes in Tetrahymena. J Mol Biol 120: 33-53, 1978.

15. Halvorsen TL, Leibowitz G and Levine F: Telomerase activity is sufficient to allow transformed cells to escape from crisis. Mol Cell Biol 19: 1864-1870, 1999.

16. Levy D, Neuhausen SL and Hunt SC: Genome-wide association identifies OBFC1 as a locus involved in human leukocyte telomere biology. Proc Natl Acad Sci USA 107: 9293-9298, 2010.

17. Melk A, Ramassar V and Helms LM: Telomere shortening in kidneys with age. J Am Soc Nephrol 11: 444-453, 2000.

18. Jung T, Bader $\mathrm{N}$ and Grune T: Lipofuscin: formation distribution and metabolic consequences. Ann NY Acad Sci 1119: 97-111, 2007.

19. Mendoz-Nunez VM,Ruiz-Ramos M and Sanchez-Rodriguez MA: Aging related oxidative stress in healthy humans. Tohoku J Exp Med 213: 261-268, 2007.

20. Janakiraman K, Chad T and Matthew R: Ink4a/Arf expression biomarker of aging. J Clin Invest 114: 1299-1307, 2004.

21. Kusumoto M, Ogawa T, Mizumoto K, Ueno H, Niiyama H, Sato N, Nakamura M and Tanaka M: Adenovirus-mediated p53 gene transduction inhibits telomerase activity independent of its effects on cell cycle arrest and apoptosis in human pancreatic cancer cells. Clin Cancer Res 5: 2140-2147, 1999.

22. De Cavanagh EM, Inserra F, Ferder L and Fraga CG: Enalapril and captopril enhance glutathione dependent antioxidant defenses in mouse tissues. Am J Physiol Regul Integr Comp Physiol 278: R572-R577, 2000

23. Michel JB, Heudes D, Michel O, Poitevin P, Philippe M, Scalbert E, Corman B and Levy BI: Effect of chronic ANG I-converting enzyme inhibition on aging processes. I. Kidney structure and function. Am J Physiol 266: R124-R135, 1994.

24. De Cavanagh EM, Piotrkowski B, Basso N, Stella I, Inserra F, Ferder L and Fraga CG: Enalapril and losartan attenuate mitochondrial dysfunction in aged rats. FASEB J 17: 1096-1098, 2003. 